\title{
Development of a large wood jam in medium-high mountains: An example of the Mazák Stream, Moravskoslezské Beskydy Mts., Czechia
}

\author{
KAREL ŠILHÁN, TOMÁŠ GALIA, VÁCLAV ŠKARPICH
}

University of Ostrava, Faculty of Science, Department of Physical Geography and Geoecology, Czechia; e-mail: Karel.Silhan@osu.cz

ABSTRACT Wood jams represent an important ecological and morphological element in fluvial systems influencing sediment / instream wood transport and storage. Therefore, the knowledge of jam ages is important in evaluating a jam's development and stability. This study presents a reconstruction of the chronological development of the largest wood jam in the wider area of the culmination peak of the Moravskoslezské Beskydy Mts. (Western Carpathians). The studied jam was composed of more than 60 logs whose morphometric parameters and orientations were recorded. Dendrochronological dating of 11 logs revealed the ages at which tree death occurred. The jam development was probably initiated in the end of 1930 s via an occurrence of debris flow that caused the channel to narrow and the wood material to start accumulating. Frequently occurring floods, together with extreme wind flow velocities, seem to be the most important factors controlling tree death and log movement from the upstream channel-reach to the jam.

KEY WORDS wood jam - dendrochronology - debris flow - flood risk - the Moravskoslezské Beskydy Mts.

ŠILHÁN, K., GALIA, T., ŠKARPICH, V. (2018): Development of a large wood jam in medium-high mountains: An example of the Mazák Stream, Moravskoslezské Beskydy Mts., Czechia. Geografie, 123, 2, 159-177.

Received May 2017, accepted March 2018.

CC Česká geografická společnost, z.s., 2018 


\section{Introduction}

Instream wood, i.e., logs, stems, branches and other fragments of trees delivered into channels, is an important component of natural channels in forested landscapes and greatly influences the morphology and dynamics of streams (Abbe, Montgomery 2003). The biological diversity and aquahabitat are especially increased when instream wood is organised into jam accumulations (Bisson et al. 1987). These wood jams strongly affect flow hydraulics and sediment connectivity within the channel system, conditioning erosion and deposition processes and resulting in changed channel dimensions (Montgomery et al. 1995; Gurnell, Sweet 1998; Wohl, Beckman 2014; Wohl 2017). Wood jams also exert a key role in trapping sediments, and the removal of instream wood from headwater streams can increase the sediment yield by an order of magnitude (Piegay, Gurnell 1997).

Abbe and Montgomery (2003) developed a typology of wood jams based on the mode of wood recruitment and the orientation of key, racked, and loose logs relative to the channel axis. Key members anchor other logs, whereas racked members are lodged against some channel obstruction (e.g., a large boulder or key member), and loose wood fills the interstitial space but adds negligible integrity to the jam. Three basic categories of wood jams were defined by these authors; these categories reflect key-member movement: in situ (autochthonous), transport (allochthonous) and combination. Headwater streams with a channel width significantly narrower than the height of riparian trees often have a low capability to move instream wood by fluvial transport, and individual logs and wood jams usually trap sediments instead of acting as sediments (Bilby, Ward 1989; Montgomery, Buffington 1997). These general trends imply the relative stability of wood jams and log steps in fluvially dominated headwaters because of their low transport capacity during ordinary flows. However, debris flows can be important agents of wood dynamics in steep mountain headwaters (May, Greswell 2003). Transport of wood represents a hazard for human society in inhabited mountain valleys because it reduces the capacity of bridge openings, contributes to scour, and increases lateral forces on bridges. This situation may lead to an increase in flooded areas or a bridge collapse (Mazzorana et al. 2009; Ruiz-Villanueva et al. 2014).

Information about the origin, development and stability of an individual wood jam is important for forest management and flood risk assessment, and when the preservation of instream wood in stream channels is ecologically beneficial. The maximal log jam age could be solved via dendrochronological approaches. This method provides an exact year of tree death and thus, a potential year of a log supply into fluvial system. Several papers from forested areas of North America and Europe documented generally longer preservation of coniferous trees in stream channels when compared to deciduous species (Hyatt, Naiman 2001; Díez et al. 2000; Dahlström, Jonsson, Nilsson 2005; Ruiz-Villanueva et al. 2016). However, 
these data were used exclusively for determination of instream wood residence time and they were not applied in the sense of wood jam stabilisation assessments. The only exceptions are the works of Jochner et al. (2015) who documented the residence time of large logs stored in jams of an Alpine stream, and Kaczka (2009) who confronted the age of wood jams in a headwater stream with the occurrence of major floods in Polish Carpathians.

The aims of this study were (i) to explain the origin and development of an exceptional large wood jam in a steep headwater, (ii) to discover its potential barrier effect on downstream wood transport, and (iii) to sketch the meteorological conditions responsible for untimely tree death and instream wood movements. The jam is located in Mazácký Grúnik natural monument (Moravskoslezské Beskydy Mts, Western Carpathians), which has been protected from human interventions, including the removal of instream wood, since the 1950s. This study provided us with a great opportunity to assess long-term dynamics of the wood jam using dendrochronological methods.

\section{Study area}

The flysch lithological structure of the Moravskoslezské Beskydy Mts (Western Carpathians), together with steep slopes and high precipitation amounts, predisposes the studied area to frequent occurrences of slope instabilities including deep-seated and shallow landslides and debris flows (Šilhán, Pánek 2010; Pánek et al. 2013; Šilhán 2012). However, the occurrence of wood jams in the channel floor is very rare. The investigated wood jam is located in the unnamed permanent tributary of the Mazák Stream draining the south-western part of the Lysá hora Mt (1,324 m a.s.l.), the highest peak of the Czech part of the Western Carpathians (Fig. 1). The drainage area upstream the wood jam is about $0.35 \mathrm{~km}^{2}$. The mean channel slope is equal to $0.16 \mathrm{~m} \cdot \mathrm{m}^{-1}$, whereas steep adjacent hillslopes usually vary between $0.8-1.0 \mathrm{~m} \cdot \mathrm{m}^{-1}$. The channel is generally confined (mean bankfull width is $\sim 2.5 \mathrm{~m}$ ), but accumulations that consist of coarse sedimentary material frequently occur between the active channel and hillslopes. The width of these accumulations varies between 1 and 5 metres, and these accumulations most likely developed as consequences of past high magnitude flood events or by reactivations of older debris flow deposits by the 'firehose effect' (Šilhán, Pánek 2010; Galia, Hradecký 2011). According to Šilhán (2015) at least five floods affected the main Mazák stream during the last 30 years (1985, 1991, 1997, 2000, and 2010). Debris flow events are not so frequent. According to Šilhán (2014) debris flow occurrence in the closes locality with known debris flow activity to studied locality (ca $1 \mathrm{~km}$ ) reaches seven events during last 75 years. The channel morphology has a steppedbed character with alterations of cascade, step-pool and rapid units and infrequent 


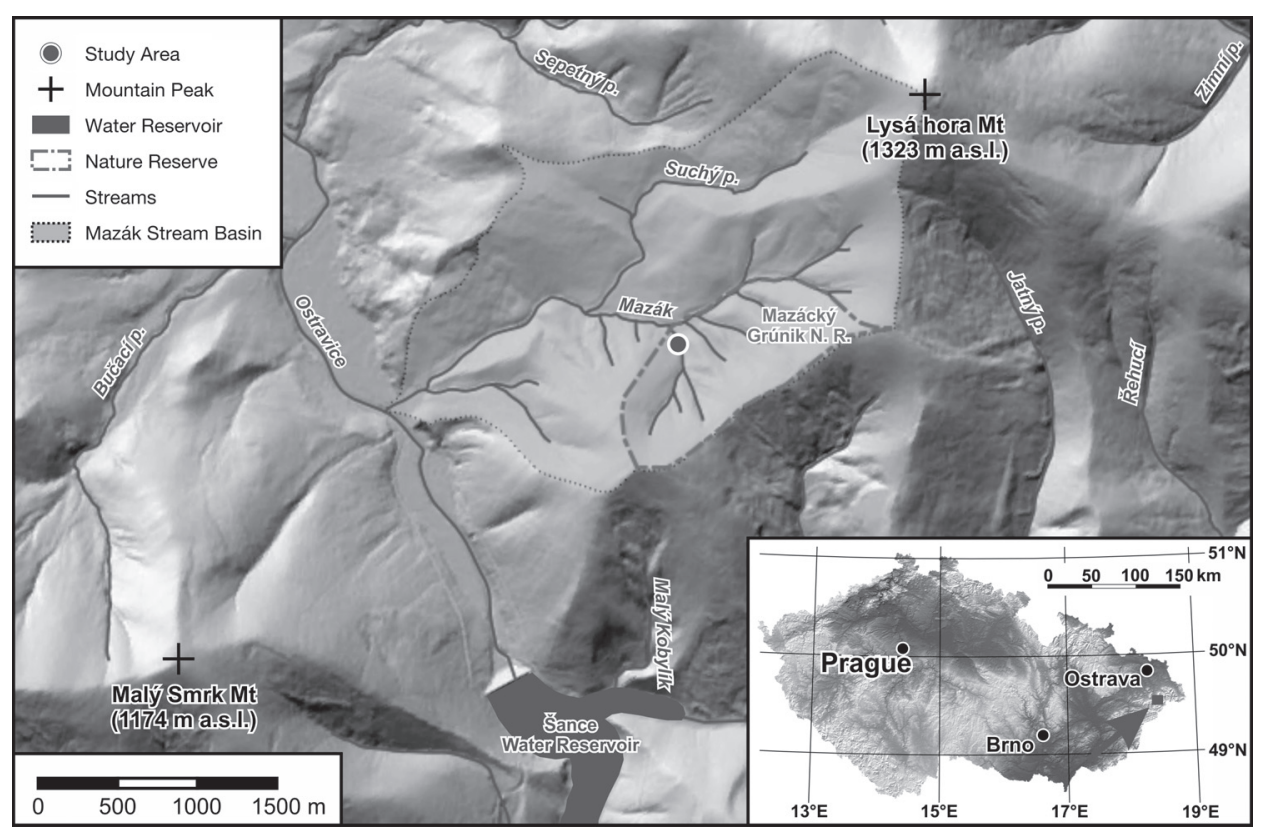

Fig. 1 - Location of the study area

bedrock steps. The occurrence of boulders $>256 \mathrm{~mm}$ in the channel is uncommon, similar to other streams based in the flysch lithology of the Western Carpathians what describes the transport conditions in the studied channel (Galia, Škarpich 2013; Galia, Hradecký 2014).

The entire length of studied tributary has been occupied by the natural protected area of Mazácký Grúnik since 1955. This protection also implies the prohibition of instream wood removal from the channel, which is an otherwise common practice in other Beskydian streams (Galia, Hradecký 2014). Forests on adjacent hillslopes mainly consist of European Beech (Fagus sylvatica L.) and Norway Spruce (Pica abies (L.) Karst.) with roughly the same representation. The studied wood jam (consisting of $>60$ wood pieces) is by far the largest one in Mazácký Grúnik and one of the largest in the Moravskoslezské Beskydy Mts. The relatively short time since the implementation of strict protection policies probably did not allow the development of other large wood jams of similar dimensions. Only small jams including $\leq 10$ woody pieces were found during the initial field mapping in the tributaries of the Mazák Stream. 


\section{Methods}

The position and dimensions of the selected log jam were geodetically measured by total station Topcon in the first phase (with $0.1 \mathrm{~m}$ precision) during the spring months in 2016. The exact position of the individual logs, bedrock outcrops, and lateral channel and the location of slope sides were spatially recorded.

Geometric parameters of all wood pieces in the jam with dimensions larger than i) $0.05 \mathrm{~m}$ in diameter and $1 \mathrm{~m}$ in length or ii) $0.1 \mathrm{~m}$ in diameter and $0.5 \mathrm{~m}$ in length were measured, and the total length and diameters at both log ends were recorded. Alternatively, the ratios of a wood length related to the valley bottom and the adjacent hillslopes were noted (i.e. the position of logs regarding the possible contact with the adjacent slope). The volumes of the individual wood pieces were calculated by approximation of the shape of the truncated cone. The orientation of logs relative to the channel axis was estimated at $\pm 22.5^{\circ}$ steps in clockwise direction; zero orientation conventionally corresponded to parallel orientation of a log to the channel axis with the thinner end in a downstream direction. In addition, all instream wood with equal size parameters was measured $100 \mathrm{~m}$ upstream (i.e., control reach) and $100 \mathrm{~m}$ downstream the studied jam to assess potential barrier effect of the jam for downstream wood movement. The positions of hillslopestabilised instream wood in the longitudinal profile were noted in the field.

An important aspect of woody jams is their temporal stability in the channel. The precise determination of jam age is a challenge that can be potentially solved in several ways (the historical orthophotos or the absolute dating of woody material incorporated in the jam). The most precise approach (with annual resolution) for assessment of temporal stability of woody jams in the forested areas seems to be dendrochronological (tree-ring based) method. Nevertheless, this approach is not suitable for all woody material and several conditions have to be fulfilled. Thus, not all but only selected logs were dendrochronologically dated. The selection of logs for dating was based on two criteria: i) the presence of the first tree ring below the bark and ii) a log diameter at least $8 \mathrm{~cm}$. This stem diameter should ensure the presence of at least 30-40 tree rings (according to the ring widths of reference trees) necessary for successful cross-dating. The samples were taken in two ways. If possible (due to a higher wood quality), increment cores were extracted with a Pressler increment borer $(\max .0 .5 \times 40 \mathrm{~cm})$. Two increment cores were taken from the opposite directions of each log. If the wood quality was low (with initial decay or insect damages), a wedge cut up to the log pith was extracted by handsaw. Moreover, 40 trees (20 F. sylvatica and 20 P. abies) were sampled (two cores per each tree) for reference chronology building. Reference trees were the oldest (with the widest stems) in the study area, with no visible external disturbance, and grew on the stable mild slope close to the studied channel. Samples were dried in the lab, and increment cores were glued into woody supports and sanded with sand papers 


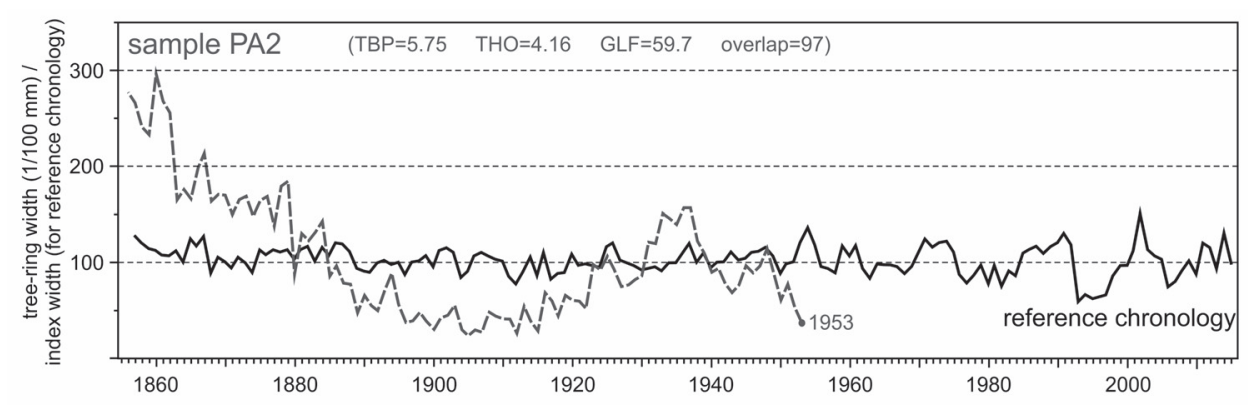

Fig. 2 - Successfully cross-dated samples of P. abies with reference chronology

(80, 250, 1,000 grit). Tree rings were counted and measured under a binocular microscope using a TimeTable measuring device and PAST4 software (VIAS 2005). The reference chronologies for each species were created in Arstan software using a double detrending procedure (Cook 1983). The mean tree ring series (the mean from two measured series per each log) from the wood jam were cross-dated with the reference chronology. The quality of cross-dating was checked using four criteria: (i) the overlap with reference chronology from at least 40 tree rings, (ii) t-test Baillie-Pilcher transformation (TBP) $>3.5$, (iii) t-test Hollstein transformation (THO) $>3.5$, and (iv) Gleichleifigkeit (Glf) $>60$. Successfully cross-dated samples are in Figure 2. The log was considered successfully cross-dated when at least three of the four fixed thresholds of the dating criteria were reached.

Possible meteorological factors influencing tree death and subsequent movement in the channel were maximal yearly wind velocity and extreme precipitation totals ( 1 day, 3 days, and 5 days). The meteorological data were obtained from the Lysá hora meteorological station (1,323 $\mathrm{m}$ a.s.l.) located ca $2 \mathrm{~km}$ north-east of the studied locality.

\section{Results}

\subsection{Wood jam morphology}

The investigated jam was the 'valley jam' category by Abbe and Montgomery (2003) classification because its width was significantly greater than the active channel width. The jam front reached ca $2.5 \mathrm{~m}$ in height, and the thickness of woody material decreased in the upstream direction. The woody material passed to the coarse sediment infill in the upper portion of the jam (Fig. 3). The logs in the jam partially laid on the old debris flow lobe in the upper portion of the jam (Fig. 3). Some large logs of P. abies were directly incorporated into the debris flow 


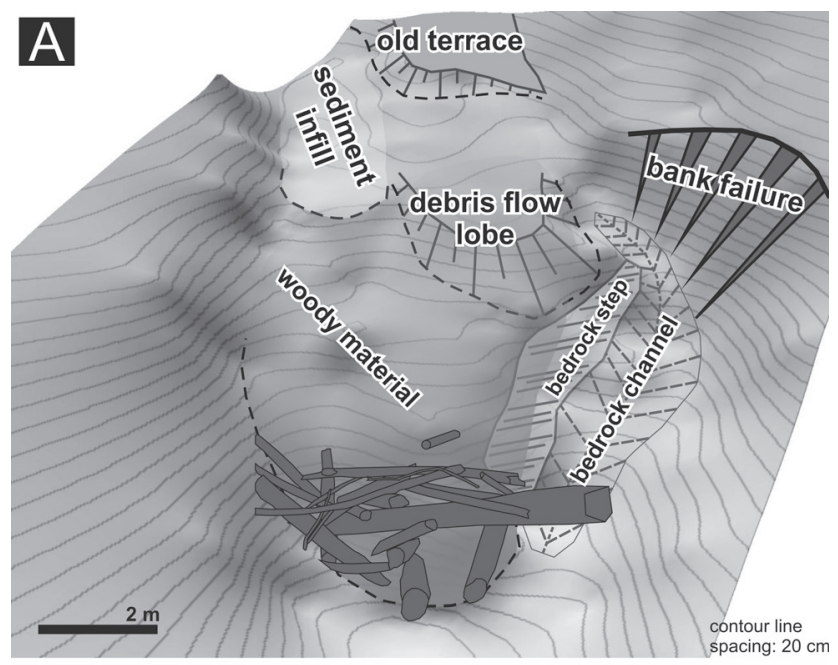

Fig. 3 - Morphology of the studied jam. A - geomorphic context of the jam, B - view of the front and middle portions of the studied woody jam.

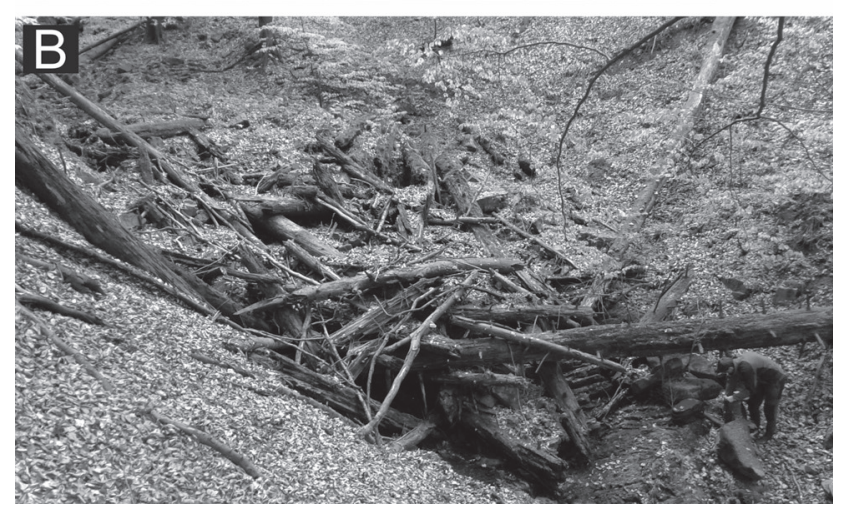

material and continued up to the front of the jam. The debris flow lobe laid directly on a ca $1.5 \mathrm{~m}$ high bedrock step of massive sandstone transverse to the channel (Fig. 3). The left border of jam was separated from adjacent hillslope by a lateral bedrock channel. There is, a ca $4 \mathrm{~m}$ high bank failure developed on the hillslope along the bedrock channel (Fig. 3). P. abies and F. sylvatica were practically the only tree species presented in the jam. Both species occurred in the upper portion of the jam and on the jam surface, whereas the jam front and inner structure of the jam were dominated by large logs of $P$. abies and coarse sediments.

\subsection{Woody material characteristics}

In total, 64 logs with sufficient dimensions by our selection methodology were included in the jam; 40 logs were classified as large wood by convent criteria ( $1 \mathrm{~m}$ in 

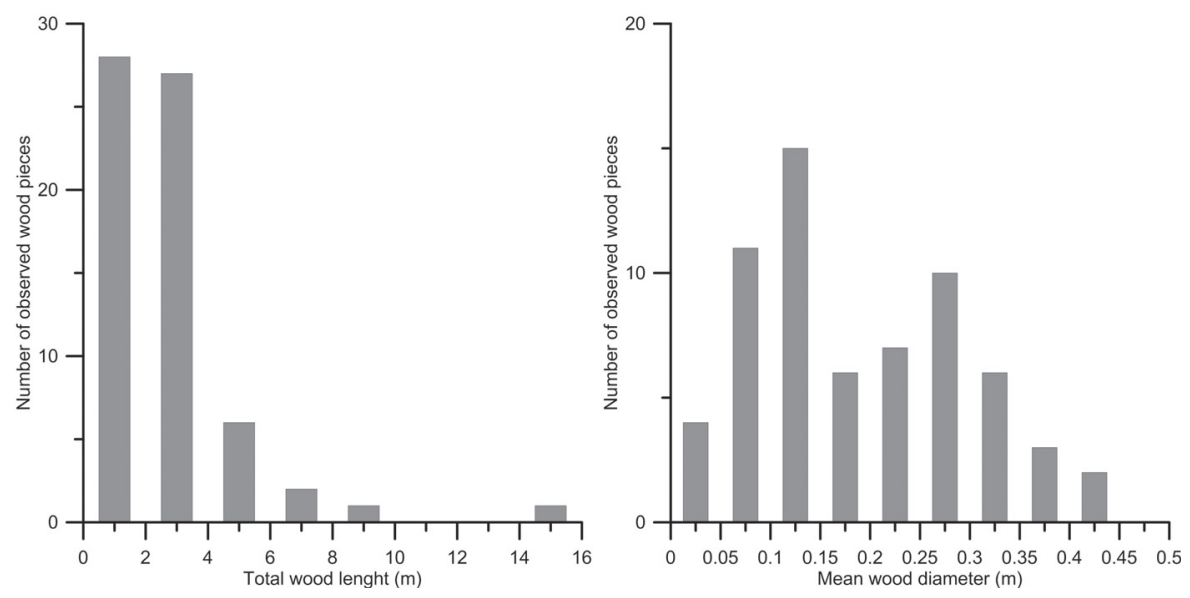

Fig. 4 - Histograms of total wood lengths at $2 \mathrm{~m}$ bins (left) and mean diameters of wood at $0.05 \mathrm{~m}$ bins (right) accumulated in the investigated wood jam.

length and $0.1 \mathrm{~m}$ in diameter according to Wohl et al. 2010). The majority of wood pieces were shorter than $5 \mathrm{~m}$. The mean length of the wood was $3.18 \mathrm{~m}$, whereas the mean diameter was $0.19 \mathrm{~m}$ (Fig. 4). Only four wood pieces were also stabilised by hillslopes; the majority of wood included in the jam was entirely placed in the valley bottom. The volume of the assessed wood material in the valley bottom was estimated to be $8.31 \mathrm{~m}^{3}$, whereas the total volume of logs, including portions attached to the hillslopes, increased to $9.11 \mathrm{~m}^{3}$. The orientation of the wood pieces is illustrated in Figure 5. Almost one-third of the pieces were oriented parallel with the channel axis, most likely corresponding to the previous transport of these logs. In contrast, several pieces not stabilised by hillslopes but with lengths between 4 and $5 \mathrm{~m}$ (i.e., slightly more than the bankfull channel width) had a perpendicular orientation.

\subsection{Instream wood distribution upstream and downstream the jam}

We investigated spatial distribution of instream wood $100 \mathrm{~m}$ upstream and $100 \mathrm{~m}$ downstream the jam in order to assess the effect of the jam on wood distribution in the downstream reach. The channel width, bed slope, adjacent hillslope gradients and forest structure was roughly the same for the entire studied longitudinal profile, which prevented from additional variations in wood loads. Only two not hillslope-attached (autochthonous) wood pieces (Fig. 6a) and noticeable decrease in instream wood volume were observed in 30-m long channel-reach immediately downstream the jam (Fig. 6b). At 30-100 m longitudinal distance downstream 

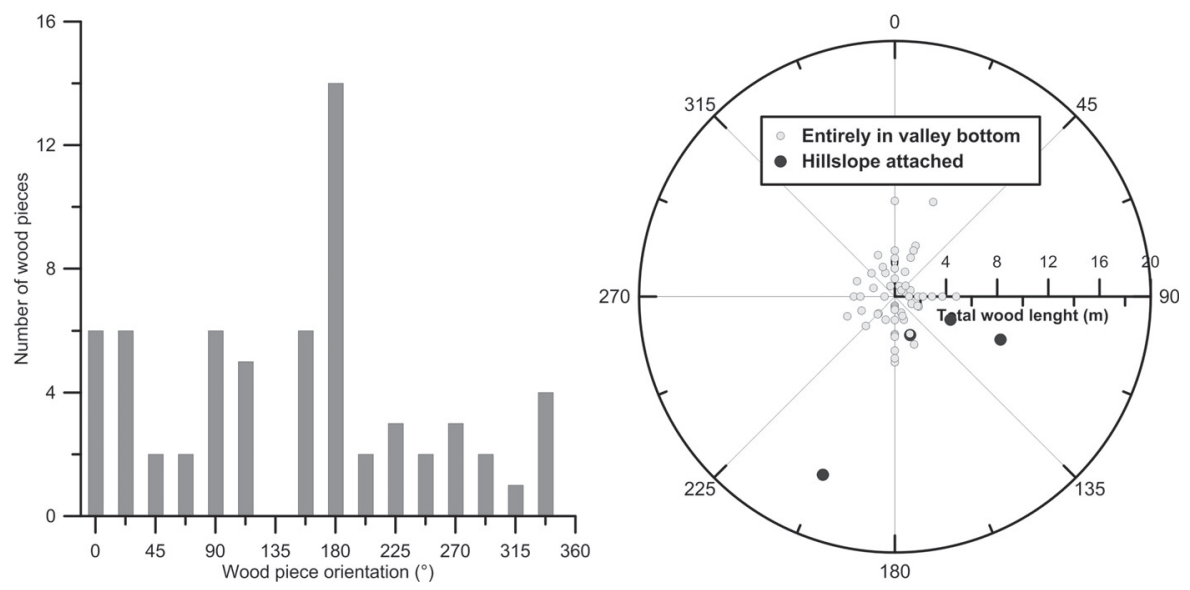

Fig. 5 - Histogram of wood pieces by orientation at $22.5^{\circ}$ bins (left) and a diagram of wood orientation based on the total wood length and the potential stabilization of pieces by hillslopes.
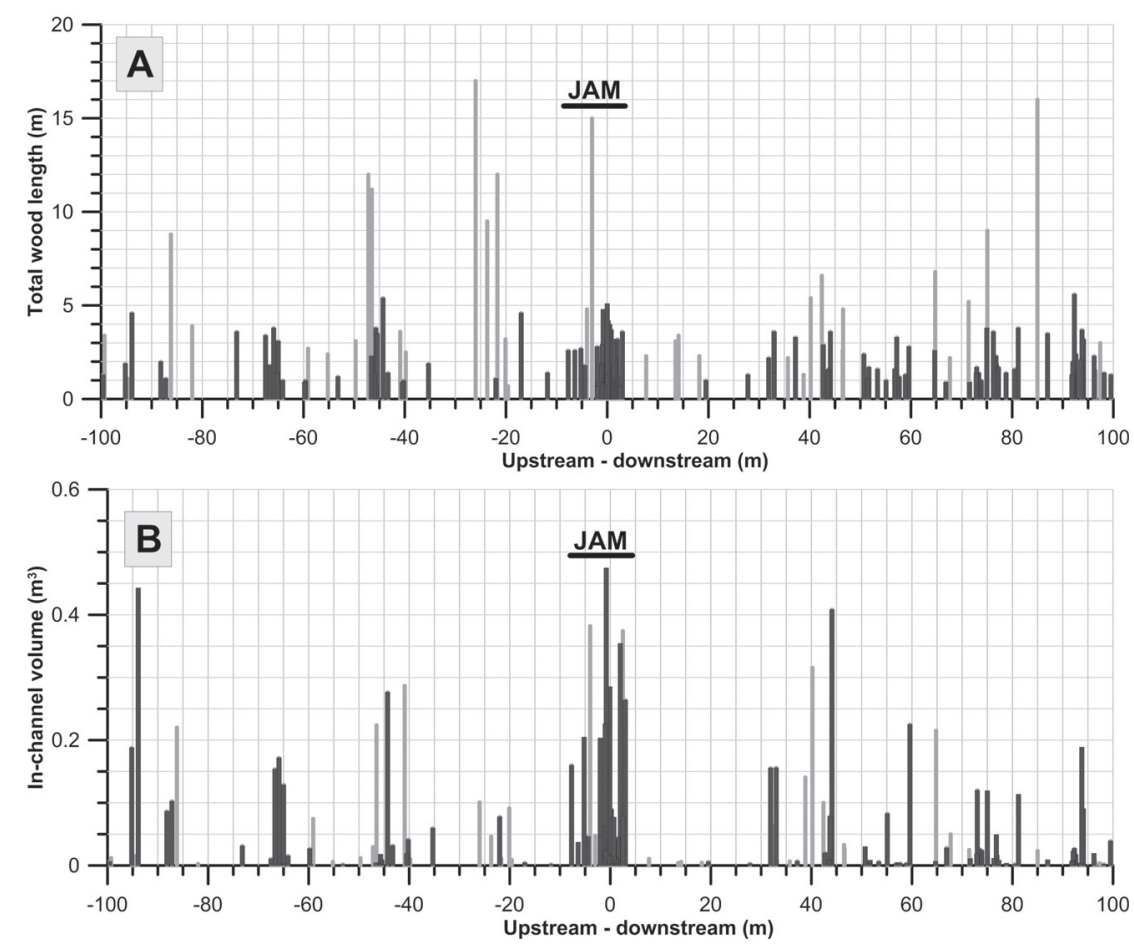

Fig. 6 - Distribution of instream wood $100 \mathrm{~m}$ upstream and downstream the studied jam. A - total wood length, B - in-channel wood volume. Grey color indicates hillslope-attached (autochthonous) wood. 


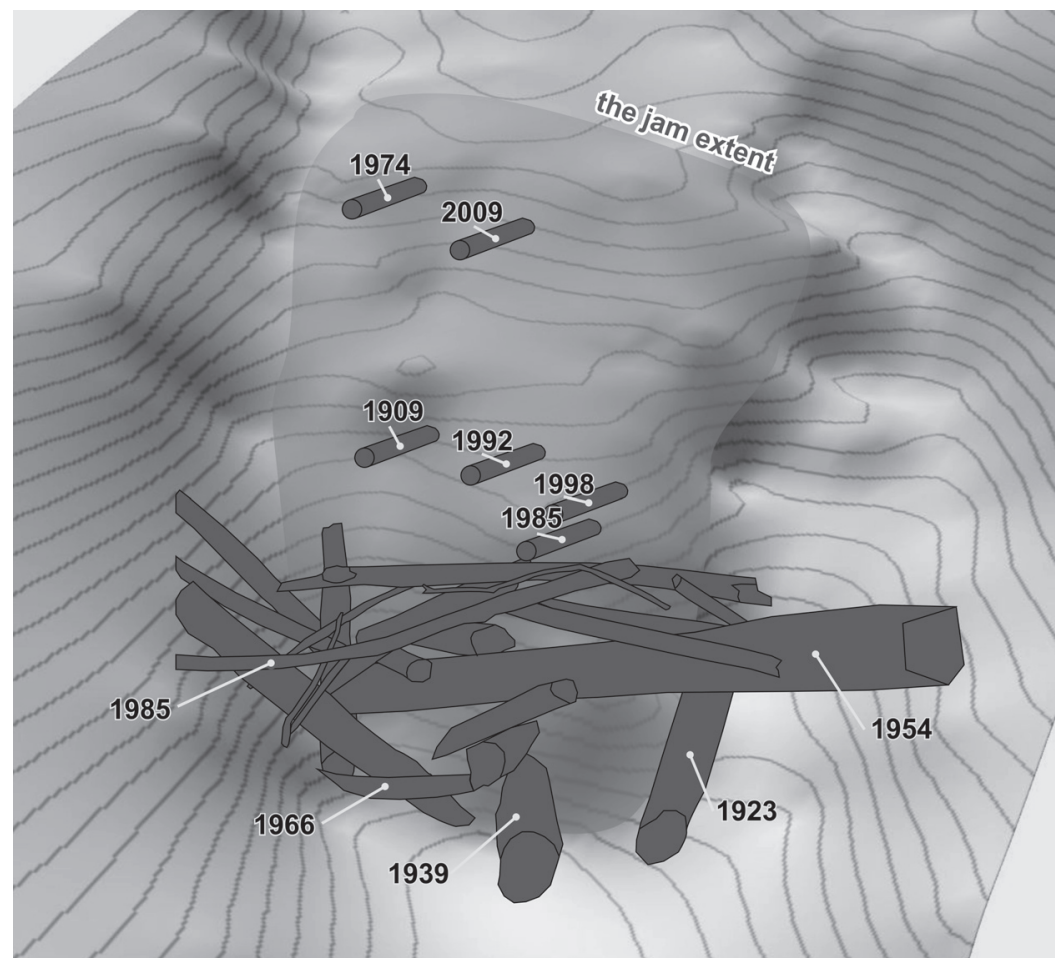

Fig. 7 - Location and dates of each cross-dated log within the woody jam

the jam, instream wood distribution was quite similar when compared to the upstream control reach.

\subsection{Dendrochronological dating}

It was possible successfully to date eleven logs in total (17.2\% of all logs in the jam) including key members (i.e. logs that build the skeleton of the jam, and answer for the jam stability). Six cross-dated logs came from the P. abies species and five came from the F. sylvatica species. Four dated logs were located at the base of the jam front (two of them were incorporated into the material of the old debris flow lobe), five logs were dated on the surface of the jam, and two logs were dated on the sediment infill dammed by the jam (Fig. 6). The mean TBP value of dated samples was 4.01 (F. sylvatica: 4.25 ; P. abies: 3.81 ), the mean THO value was 3.74 (F. sylvatica: 3.70; P. abies: 3.77), the mean GLF value was 69.87 (F. sylvatica: 70.64; P. abies: 69.23), and the mean overlap with reference chronology was 43.1 years (F. sylvatica: 40.20; P. abies: 45.50). Details about all cross-dated logs are provided in Tab. 1. The mean 
age at which the trees died was 48.9 years (stdev: 32.3 years). P. abies logs were preserved for a significantly longer time (mean: 67.5 years; stdev: 31.2 years) in the jam than F. sylvatica logs (mean: 27.4 years; stdev: 16.1 years) on average (p-value from U-test: 0.03). The oldest dated logs occurred at the base of jam front and in the material of the debris flow lobe (AD 1923 and AD 1939, respectively). Both logs are key members responsible for jam stability. The next key member was dated to 1954. The youngest (AD 2009) log was localized above the sediment infill. The logs located on the jam surface revealed the wide age range between AD 1909 and AD 1998; nevertheless, seven of nine logs were dated in a period of 59 years (from $\mathrm{AD} 1939$ to AD 1998). Figure 7 summarizes the positions of all the cross-dated logs with their age of death.

\subsection{Meteorological conditions during dated tree death}

All 11 cross-dated logs died in ten years (Table 1). The mean maximal one-day precipitation total in these years was $89.1 \mathrm{~mm}$ (the mean one-day precipitation for the period 1897-2009 was $4.0 \mathrm{~mm}$ ), reflecting the Lysá hora Mt. station. The highest one-day precipitation occurred in 1985 (137.7 mm), and the lowest occurred in 1923 (41.4 mm). The maximal one-day precipitation in cross-dated years were evenly distributed through a year. The mean maximal three-day precipitation was $161.9 \mathrm{~mm}$ (the long-term mean three-day precipitation value was $11.3 \mathrm{~mm}$ ). The maximal three-day precipitation occurred in $1985(267.1 \mathrm{~mm})$, and the minimal three-day precipitation occurred in $1992(82.6 \mathrm{~mm})$. The maximal three-day precipitation were evenly distributed through a year as well. The mean maximal five-day precipitation was $179.8 \mathrm{~mm}$, whereas the long-term mean five-day

Table 1 - The overview of cross-dated samples

\begin{tabular}{llllccc}
\hline Sample ID & Species & TBP & THO & GLF & Overlap & Outermost ring (years AD) \\
\hline PA1 & P. abies & 3.50 & 4.16 & 71.20 & 58 & 1954 \\
PA2 & P. abies & 3.99 & 3.13 & 63.30 & 45 & 1923 \\
PA3 & P. abies & 3.55 & 3.02 & 68.10 & 41 & 1939 \\
PA4 & P. abies & 4.76 & 5.05 & 66.00 & 50 & 1974 \\
PA5 & P. abies & 5.75 & 4.16 & 59.70 & 97 & 1992 \\
PA6 & P. abies & 3.20 & 3.57 & 82.30 & 41 & 1909 \\
FS1 & F. sylvatica & 4.39 & 4.08 & 80.00 & 40 & 1966 \\
FS2 & F. sylvatica & 4.67 & 3.85 & 72.50 & 42 & 1985 \\
FS3 & F. sylvatica & 4.40 & 3.57 & 65.80 & 39 & 2009 \\
FS4 & F. sylvatica & 3.68 & 3.86 & 66.10 & 38 & 1985 \\
FS5 & F. sylvatica & 4.12 & 3.14 & 68.80 & 42 & 1998 \\
\hline
\end{tabular}


Table 2 - The overview of extreme precipitation totals and wind events in cross-dated years ( $\mathrm{x}$ - no data)

\begin{tabular}{llrrrrrrrr}
\hline Sample ID & $\begin{array}{l}\text { Cross-dated } \\
\text { year }\end{array}$ & $\begin{array}{c}\text { One-day } \\
\text { precipitation }\end{array}$ & Date & $\begin{array}{c}\text { Three-days } \\
\text { precipitation }\end{array}$ & Date & $\begin{array}{c}\text { Five-days } \\
\text { precipitation }\end{array}$ & Date & $\begin{array}{c}\text { Wind } \\
\left(\mathrm{m} \cdot \mathrm{s}^{-1}\right)\end{array}$ & Date \\
\hline PA1 & 1954 & $\times$ & $\times$ & $\times$ & $\times$ & $\times$ & $\times$ & $\times$ & $\times$ \\
PA2 & 1923 & 41.4 & 31.12. & 83.2 & 31.12. & 89.6 & 31.12. & $\times$ & $\times$ \\
PA3 & 1939 & 132.0 & 26.7. & 218.8 & 27.7. & 229.5 & 28.7. & 19.0 & 24.2. \\
PA4 & 1974 & 69.3 & 19.1. & 121.9 & 20.1. & 143.6 & 21.1. & 23.7 & 15.11. \\
PA5 & 1992 & 49.4 & 6.12. & 82.6 & 6.12. & 101.1 & 5.9. & 17.3 & 1.4. \\
PA6 & 1909 & 56.2 & 14.6. & 121.6 & 14.6. & 134.8 & 14.6. & $\times$ & $\times$ \\
FS1 & 1966 & 80.4 & 29.5. & 161.4 & 25.7. & 188.8 & 1.6. & 21.7 & 5.12. \\
FS2 & 1985 & 137.7 & 8.8. & 267.1 & 9.8. & 282.8 & 10.8. & 20.0 & 5.11. \\
FS3 & 2009 & 99.8 & 14.10. & 165.3 & 14.10. & 211.7 & 15.10. & 21.3 & 30.11. \\
FS4 & 1985 & 137.7 & 8.8. & 267.1 & 9.8. & 282.8 & 10.8. & 20.0 & 5.11. \\
FS5 & 1998 & 87.4 & 28.9. & 130.2 & 13.6. & 133.1 & 15.6. & 18.3 & 31.12. \\
Long-term & mean & 4.0 & & 11.3 & & 18.9 & & 6.6 & \\
\hline
\end{tabular}

precipitation was $18.9 \mathrm{~mm}$. The maximal five-day precipitation occurred in 1985 $(282.8 \mathrm{~mm})$, and the minimal five-day precipitation occurred in $1923(89.6 \mathrm{~mm})$. The maximum daily wind speed for eight cross-dated years (only accessible data) was $20.2 \mathrm{~m} \cdot \mathrm{s}^{-1}$, whereas the long-term daily mean was $6.6 \mathrm{~m} \cdot \mathrm{s}^{-1}$. The days with maximal annual wind velocity occurred during the cold half of the year between November 5 and April 1. Table 2 shows details about the observed precipitation and wind velocity extremes.

\section{Discussion}

The chronological development of the largest wood jam in the surroundings of the Lysá hora Mt., which consisted of more than 60 pieces of instream wood, was reconstructed using dendrochronological methods. In total, 11 logs were crossdated, and the years of trees death were compared with precipitation and wind extremes. The limited number of dated logs is caused by strict conditions for successful tree-ring based dating. Unfortunately, it seems to be almost impossible to date the death of logs in the jam with annual precision by some another method (e.g. radiocarbon AMS method). Nevertheless, even limited number of dated logs can provide important information regarding the jam age and thus its stability in the channel. This is also our case, because several key members anchoring the other logs were successfully dated. Our research provided information about high stability of the jam with more than 70 years old history. 


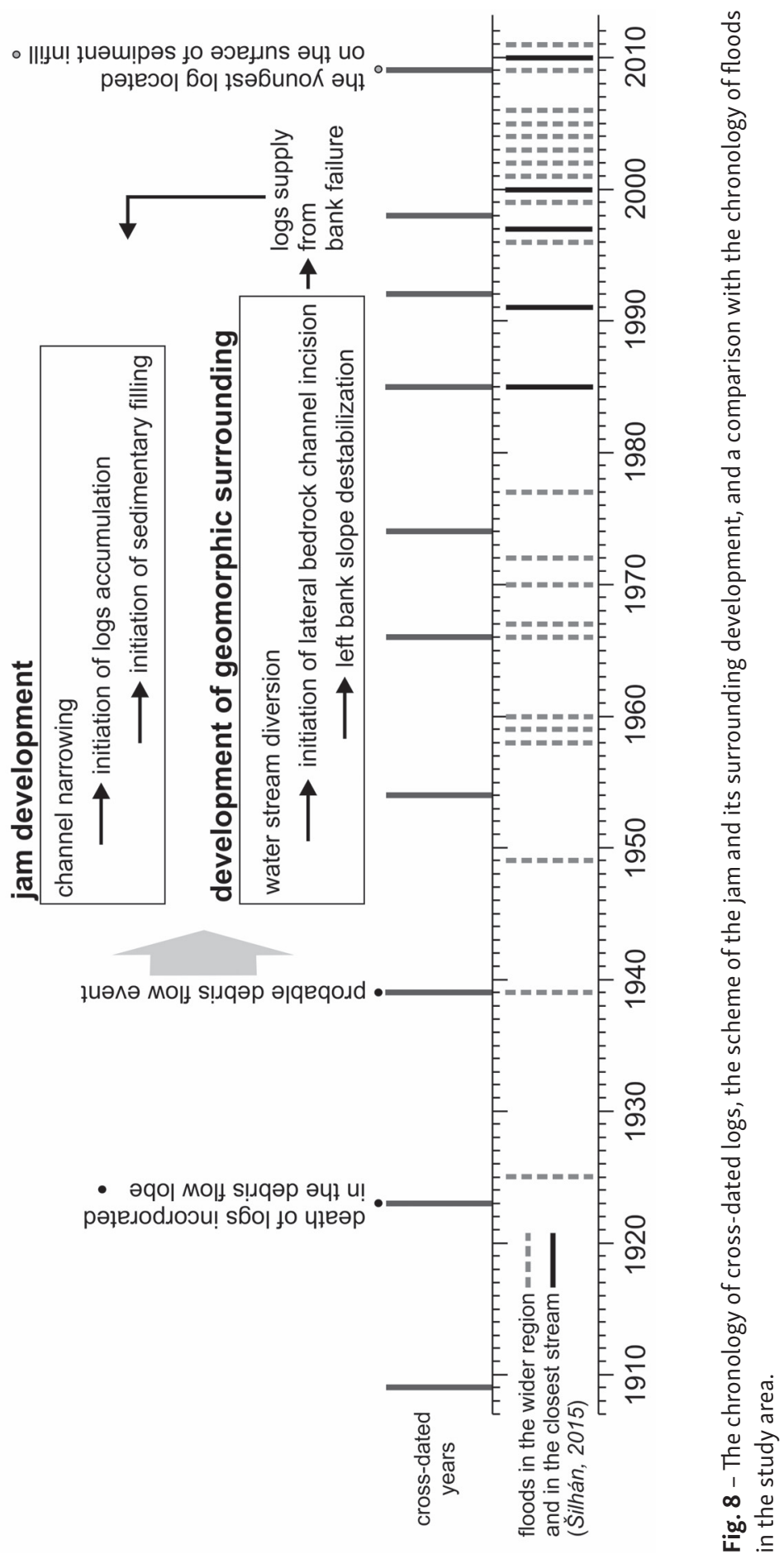




\subsection{Hypothetical origin of the jam}

The jam is located in a position with very specific channel conditions. The bedrock step and debris-flow lobe could have played an important role during the start of the jam creation. The debris flow lobe that is located immediately upstream of the jam is clearly older than the jam itself. Our opinion is based on the chronological dating of logs incorporated into the debris flow material and free logs in the jam. The debris flow accumulation probably caused the narrowing of the channel and decreased the ability of log transport through this portion of the valley floor. This effect is still functional in present days. Thus, the time that the debris flow lobe originated could be the starting moment of jam formation. The question is the age of the debris flow and the initiation of jam formation. Fortunately, the debris flow lobe had incorporated several logs in its sediments. Two of these logs could be dated dendrochronologically. The cross-dating revealed the oldest age (except the log from 1909) of tree death from all dated logs, which clearly supported the hypothesis that the debris flow was a triggering factor for jam creation. The cross-dated ages of logs in the debris flow lobe were AD 1923 and AD 1939. As the age of logs since their death signifies the maximal age of debris flow, the debris flow event alone originated in 1939 or later. The existence of debris flow in the Moravskoslezské Beskydy Mts. was minimal in the 1930s (Šilhán, Pánek 2010; Šilhán 2014). Nevertheless, large debris flow events with regional extension occurred right in AD 1939 (Šilhán, Pánek 2010; Šilhán 2014). Moreover, several flood and landslide events occurred in the close vicinity of studied locality during this year (Šilhán et al. 2013, 2014; Šilhán 2015; Fig. 8). Thus, it is possible that the debris flow in the study area and the start of jam formation occurred in this year as well. This finding is in contrast with general assumptions, where debris flows are usually understood as processes that destroy log jams with their scours in low-order streams (May, Gresswell 2003). The presence of logs in the debris flow lobe indicated the first case, when the initial occurrence of instream wood in the channel contributed to the origin of debris flow accumulation at its present position (i.e., without reaching a low-gradient reach or junction with the main stream - see Fig. 7). The later development of the jam dominated by consequent deposition of logs fluvially transported from upstream reaches or by logs supplied from adjacent hillslopes.

\subsection{Jam development and implications for flood risk assessment}

After the initiation of jam creation due to possible debris flow occurrence probably in 1939 (the youngest death moment of the log - key member - incorporated in the debris flow material), the subsequent accumulation of woody material started 
in the location of the narrowed channel. Based on the cross-dating of logs located in various portions of the jam except the piece from 1909 (discussed later), the accumulation of logs was more or less regular during the post-debris flow period (1939-2009). The stratigraphy of the jam is in the vertical direction composed of logs with subsequently decreasing time since their depth (key members in 1939, 1954,1985 and another minor log in 1966). The jam base is actually dominated by the presence of large P. abies logs. F. sylvatica material disintegrates more quickly than P. abies material does (Šamonil et al. 2009; Holeksa, Zielonka, Żywiec 2008); thus, the oldest portions of the jam are predominantly occupied by large P. abies logs. Woody material accumulation, together with the gradual upstream accumulation of coarse sediments, resulting in the upstream accretion of sediment infill.

Debris flow accumulation probably influenced the diversion of the main flow to the left bank, which is evidenced by the formation of a lateral bedrock channel between the jam and adjacent hillslope. Water flowing in this bedrock channel undercut the adjacent hillslope and gradually created the large bank failure. Trees growing on the affected hillslope were subsequently destabilized, and they directly supplied the jam. The woody material supply into the jam is still continuing by fluvial transport from upstream channel reaches; the youngest log (AD 2009) is localized on the beginning of the jam on the surface of sediment infill, but even older log (AD 1974) reached the jam (Fig. 7).

It is also notable that several wood pieces longer than $4 \mathrm{~m}$ (i.e., more than the bankfull channel width) but not attached by hillslopes had perpendicular orientation. This suggests that their deposition in the jam occurred during high magnitude floods accompanied by hyperconcentrated or small debris flows as evidenced e.g. by Shrestha et al. (2012). This finding also implies that a log slightly larger than the bankfull channel width can be transported downstream in a steep low-order channel with assumed low transport capacity (e.g., Montgomery, Buffington 1997).

In contrast, the investigated wood jam remained a stable element during past floods, causing important barrier for instream wood transport. The jam functions as a net build from logs that catch next coming woody material. This material contributes to jam growing. The bigger jam is the more effective interception of coming woody material. In our case, the significance as a transport barrier is evident, because we observed $30-\mathrm{m}$ long reach immediately downstream the jam which was practically without instream wood. This fact indirectly corresponds to the observations of Wohl and Cadol (2011), who documented frequent aggregation of individual wood pieces into jams by fluvial transport. In this instance, such large wood jams in narrow mountain headwaters can reduce the potential negative effects of transported wood on the infrastructure. In Polish Carpathians, Kaczka (2009) reported that the majority of wood jams in a headwater channel survived several significant flood events during past decades. It is known that the stability of individual jams should be carefully considered in view of the flood risk. 
With respect to wood decay and the observed cross-dated ages of the logs, P. abiesdominated wood jams would be more stable than jams containing F. sylvatica as key logs. One should also assess the potential mobility of wood pieces in the examined stream, i.e., the period between the death of a tree and its incorporation into the log jam.

\subsection{Meteorological conditions possibly responsible for tree death and log movements}

One of the most important meteorological factors that influence tree death is wind velocity (Šamonil et al. 2013). The maximal daily wind velocities in the years of tree deaths are more than three times higher than the long-term mean. Moreover, the effect of wind can be even stronger when the soil layer is saturated by water. These conditions possibly occurred in most of the dated years (Table 2).

Defining the conditions responsible for the log supply to the jam is much more difficult, as the cross-dated years show only the time of tree death. In our case, we assume a rather short lapse time periods between dated tree deaths and their entrance into the fluvial systems due to the presence of very steep hillslopes. Moreover, most of dated trees died in a year with strong wind occurrences. Thus, the supply of the majority of trees to the channel can be expected to occur without any significant delay after tree death. The next uncertainty is how long the log remained in the channel before its incorporation into the jam. Because most of the cross-dated years of death corresponded to extreme precipitation totals and because most of the trees were probably affected by windthrow (and immediately supplied into the channel), the time between tree death and reaching the jam could be short. As the frequency of floods in the study area is quite high (Šilhán 2015), the time between the supply to the channel and reaching the jam could also be short.

\section{Conclusions}

Large wood jams are a rare phenomenon in the managed forests of the Czech Western Carpathians. Dendrochronological dating (via a cross-dating method) established the chronology of the wood jam origin and its development. Although only limited number of logs were dated, important information about the jam age was possible to assess because several key members were among the successfully dated logs. In this sense the dendrochronological methods seems to be very suitable tool for the woody jam age determination because another possible method (analysis of historical orthophotos or radiocarbon dating) cover limited time span or express inappropriate temporal resolution. 
We documented that the present position of the jam was predisposed by the occurrence of debris flow due to dated logs in the debris flow lobe (tree death in 1920s and 1930s). Moreover, the tree-ring based dating of key member logs in the jam provided the information about high stability of the jam because it is in the stable position already more than 70 years. This accumulation changed the valley morphology, and many logs were deposited in the narrower channel in the following decades until the present, where the youngest logs in the upstream portion of the jam were dated to the 2010s. An additional hillslope wood supply (four pieces) contributed to the present shape of the jam. In this manner, the jam acts as a barrier for downstream wood movement but has remained stable itself during the last flood events. Two woody species dominated the jam mass, and P. abies has a higher resistance against decomposition processes than $F$. sylvatica ones. The extreme wind flow velocities, in combination with a saturated soil layer and flooding events, seems to be the most important factor controlling tree death and the log supply to the jam.

\section{References}

ABBE, T.B., MONTGOMERY, D.R. (2003): Patterns and processes of wood debris accumulation in the Queets River basin, Washington. Geomorphology, 51, 81-107.

BILBY, R.E., WARD, J.W. (1989): Changes in characteristics and function of woody debris with increasing stream size in western Washington. Transactions of American Fisheries Society, $118,368-378$.

BISSON, P.A., BILBY, R.E., BRYANT, M.D., DOLLOFF, C.A., GRETTE, G.B., HOUSE, R.A., MURPHY, M.L., KOSHI, K.V., SEDELL, J.R. (1987): Large woody debris in forested streams in the Pacific northwest: past, present, and future. In: Salo, E.O., Cundy, T.W. (eds.): Streamside Management: Forestry and Fishery Interactions. Institute of Forest Resources, University of Washington, Seattle, 143-190.

COOK, E.R. (1983): A time series analysis approach to tree-ring standardization. PhD Dissertation, University of Arizona: Tucson, USA.

DAHLSTRÖM, N., JONSSON, K., NILSSON, C. (2005): Long-term dynamics of large woody debris in a managed boreal forest stream. Forest Ecology and Management, 210, 363-373.

DÍEZ, J., ELOSEGI, A., CHAUVET, E., POZO, J. (2000): Breakdown of wood in the Agüera stream. Freshwater Biology, 47, 2205-2215.

GALIA, T., HRADECKÝ, J. (2011): Bedload transport and morphological effects of high-magnitude floods in small headwater streams - Moravskoslezské Beskydy Mts. (Czech Republic). Journal of Hydrology and Hydromechanics, 59, 238-250.

GALIA, T., HRADECKÝ, J. (2014): Morphological patterns of headwater streams based in flysch bedrock: Examples from the Outer Western Carpathians. Catena, 119, 174-183.

GALIA, T., ŠKARPICH, V. (2013): Coarse bed sediments in a headwater channel as indicators of fluvial and slope-channel coupling: a case study from the Carpathian mountains (Czech republic). Moravian Geographical Reports, 21, 2-12.

GURNELL, A.M., SWEET, R. (1998): The distribution of large woody debris accumulations and pools in relation to woodland stream management in a small, low gradient stream. Earth Surface Processes and Landforms, 23, 1101-1121. 
HOLEKSA, J., ZIELONKA, T., ŻYWIEC, M. (2008): Modeling the decay of coarse woody debris in a subalpine Norway spruce forest of the Western Carpathians, Poland. Canadian Journal of Forest Research, 38, 415-428.

HYATT, T.L., NAIMAN R.J. (2001): The residence time of large woody debris in the Queets River, Washington, USA. Ecological Applications, 11, 191-202.

JOCHNER, M., TUROWSKI, J.M., BADOUX, A., STOFFEL, M., RICKLI, C. (2015): The role of log jams and exceptional flood events in mobilizing coarse particulate organic matter in a steep headwater stream. Earth Surface Dynamics Discusses, 3, 173-196.

KACZKA, R. (2009): Dynamics of large woody debris and wood dams in mountain Kamienica Stream, Polish Carpathians. In: Kaczka, R., Malik, I., Owczarek, P., Gärtner, H., Helle, G., Heinrich, I. (eds.), TRACE - Tree Rings in Archaeology, Climatology and Ecology. GFZ Potsdam, 171-175.

MAY, C.L., GRESSWELL, R.E. (2003): Processes and rates of sediment and wood accumulation in headwater streams of the Oregon Coast Range, USA. Earth Surface Processes and Landforms, 28, 409-424.

MAZZORANA, B., ZISCHG, A., LARGIADER, A., HÜBL, J. (2009): Hazard index maps for woody material recruitment and transport in alpine catchments. Natural Hazards and Earth System Science, 9, 197-209.

MONTGOMERY, D.R., BUFFINGTON, J.M. (1997): Channel-reach morphology in mountain drainage basins. Geological Society of America Bulletin, 109, 596-611.

MONTGOMERY, D.R., BUFFINGTON, J.M., SMITH, R.D., SCHMIDT, K.M., PESS, G. (1995): Pool spacing in forest channels. Water Resources Research, 31, 1097-1105.

PÁNEK, T., SMOLKOVÁ, V., HRADECKÝ, J., BAROŇ, I., ŠILHÁN, K. (2013): Holocene reactivations of catastrophic complex flow-like landslides in the Flysch Carpathians (Czech Republic/ Slovakia). Quaternary Research, 80, 33-46.

PIEGAY, H., GURNELL, A.M. (1997): Large woody debris and river geomorphological pattern: examples from S.E. France and S. England. Geomorphology, 19, 99-116.

RUIZ-VILlANUEVA, V., CASTELlET, E.B., DIEZ-HERRERO, A., BODOQUE, J.M., SANCHEZ-JUNY, M. (2014): Two-dimensional modelling of large wood transport during flash floods. Earth Surface Processes and Landforms, 39, 438-449.

RUIZ-VILLANUEVA, V., PIÉGAY, H., GURNELL, A.A., MARSTON, R.A., STOFFEL, M. (2016): Recent advances quantifying the large wood dynamics in river basins: New methods and remaining challenges. Review of Geophysics, 54.

ŠAMONIL, P., ANTOLÍK, L., SVOBODA, M., ADAM, D. (2009): Dynamics of windthrow events in a natural fir-beech forest in the Carpathian mountains. Forest Ecology and Management, 257, 1148-1156.

ŠAMONIL, P., SCHAETZL, R.J., VALTERA, M., GOLIÁŠ, V., BALDRIAN, P., VAŠÍČKOVÁ, I., ADAM, D., JANÍK, D., HORT, L. (2013): Crossdating of disturbances by tree uprooting: Can treethrow microtopography persist for 6,000 years? Forest Ecology and Management, 307, 123-135.

SHRESTHA, B.B., NAKAGAWA, H., KAWAIKE, K., BABA, Y., ZHANKG, H. (2012): Driftwood deposition from debris flows at slit-check dams and fans. Natural hazards, 61, 577-602.

ŠILHÁN, K. (2012): Dendrogeomorphological analysis of the evolution of slope processes on flysch rocks (Vsetínské vrchy Mts; Czech Republic). Carpathian Journal of Earth and Environmental Sciences, 7, 39-49.

ŠILHÁN, K. (2014): Chronology of processes in high-gradient channels of medium-high mountains and their influence on alluvial fans properties. Geomorphology, 206, 288-298. 
ŠILHÁN, K. (2015): Frequency, predisposition and triggers of floods in Flysch Carpathians: regional study using dendrogeomorphic methods. Geomorphology, 234, 243-253.

ŠILHÁN, K., PÁNEK, T. (2010): Fossil and recent debris flows in medium-high mountains (Moravskoslezské Beskydy Mts, Czech Republic). Geomorphology, 124, 238-249.

ŠILHÁN, K., PÁNEK, T., DUŠEK, R., HAVLŮ, D., BRÁZDIL, R., KAŠIČKOVÁ, L., HRADECKÝ, J. (2013): The dating of bedrock landslide reactivations using dendrogeomorphic techniques: the Mazák landslide, Outer Western Carpathians (Czech Republic). Catena, 104, 1-13.

ŠILHÁN, K., PÁNEK, T., TURSKÝ, O., BRÁZDIL, R., KLIMEŠ, J., KAŠIČKOVÁ, L. (2014): Spatio-temporal patterns of recurrent slope instabilities affecting undercut slopes in flysch: a dendrogeomorphic approach using broad-leaved trees. Geomorphology, 213, 240-254.

VIAS (2005): Vienna Institute of Archaeological Science: Time Table. Installation and instruction manual. Ver. 2.1, Vienna.

WOHL, E. (2017): Bridging the gaps: An overview of wood across time and space in diverse rivers. Geomorphology, 279, 3-26.

WOHL, E., BECKMAN, N.D. (2014): Leaky rivers: implications of the loss of longitudinal fluvial disconnectivity in headwater streams. Geomorphology, 205, 27-35.

WOHL, E., CADOL, D. (2011): Neighbourhood matters: patterns and controls on wood distribution in old-growth forest streams of the Colorado Front Range. Geomorphology, 125, 132-146.

WOHL, E., CENDERELLI, D.A., DWIRE, K.A., RYAN-BURKETT, S.E., YOUNG, M.K. FAUSCH, K.D. (2010): Large in-stream wood studies: a call for common metrics. Earth Surface Processes and Landforms, 35, 618-625.

\section{ACKNOWLEDGEMENTS}

English language was reviewed by American Journal Experts. 